\title{
PENANGANAN INFEKSI SALURAN PERNAPASAN AKUT (ISPA) PADA ANAK DI RUMAH RT 13 KELURAHAN PULOKERTO KECAMATAN GANDUS PALEMBANG
}

\author{
Lily Marleni ${ }^{1 *}$, Sintiya Halisya ${ }^{2}$, Tafdhila ${ }^{3}$, Zuhana ${ }^{4}$, Annisa Salsabila ${ }^{5}$, Deatry \\ Adel Meijery ${ }^{6}$, Eka Risma ${ }^{7}$ \\ ${ }^{1-7}$ Prodi D-III Keperawatan STIK Siti Khadijah Palembang \\ Email Korespondensi: lilyasheeqa@gmail.com
}

Disubmit: 01 Oktober 2021

Diterima: 04 Desember 2021

Diterbitkan: 01 Januari 2022

DOI: https://doi.org/10.33024/jkpm.v1i1.5226

\begin{abstract}
ABSTRAK
ISPA adalah penyebab utama morbiditas dan mortalitas penyakit menular di dunia. Hampir empat juta orang meninggal akibat ISPA setiap tahunnya Selain itu, ISPA merupakan penyebab utama konsultasi atau rawat inap di fasilitas pelayanan kesehatan terutama pada bagian perawatan anak. Beberapa peranan ibu dalam melakukan upaya perawatan ISPA pada anaknya yaitu ibu harus mengetahui tentang ISPA mulai dari pengertian, penyebab, tanda dan gejala, proses perjalanan penyakit, komplikasi dan cara mengobati dan merawat anak semasa sakitnya tersebut agar bisa melakukan perawatan sedini mungkin dan sudah tahu bagaimana cara pencegahan ISPA tersebut. Oleh karena itu perlu dilakukan penyuluhan tentang penanganan ISPA. Sasaran dalam kegiatan ini adalah masyarakat di RT.13 Kelurahan Pulokerto Kecamatan Gandus Palembang. Kegiatan dilaksanakan pada tanggal 24 Juli 2021. Pengabdian masyarakat dengan topik "Penanganan ISPA pada Anak khususnya di RT 13 Kelurahan Pulokerto Kecamatan Gandus Palembang Tahun 2021" telah terlaksana dengan baik. Terdapat peningkatan pengetahuan masyarakat mengenai penanganan ISPA pada anak. Diharapkan kepada masyarakat untuk dapat menjaga lingkungan rumah dan dapat menerapkan Perilaku Hidup Bersih dan Sehat
\end{abstract}

Kata Kunci: ISPA, Pelayanan Kesehatan, Perawatan

\section{ABSTRACT}

Acute Respiratory Infections are the leading cause of infectious disease morbidity and mortality in the world. Nearly four million people die from ARI every year. In addition, ISPA is the main cause of consultation or hospitalization in health care facilities, especially in the child care section. Some of the roles of mothers in making efforts to treat ARI in their children, namely mothers must know about ISPA starting from the understanding, causes, signs and symptoms, the course of the disease, complications and how to treat and care for children during their illness so that they can take care as early as possible and already know how how to prevent the ISPA. Therefore, it is necessary to conduct counseling on the handling of ISPA. The target in this activity is the community in RT.13 Pulokerto Village, Gandus District, Palembang. The activity was carried out on July 24, 2021. Community service with the topic "Handling ARI in Children, especially in RT 13, Pulokerto Village, Gandus District, Palembang in 
2021" has been carried out well. The local community has received counseling and clear and easy-to-understand explanations regarding the handling of ISPA in children. It is hoped that the community will be able to maintain the home environment and be able to implement a Clean and Healthy Lifestyle.

Keywords: ISPA, Health Services, Care

\section{PENDAHULUAN}

Infeksi Saluran Pernapasan Akut (ISPA) adalah infeksi akut yang menyerang salah satu bagian atau lebih dari saluran napas mulai hidung sampai alveoli termasuk adneksanya (sinus, rongga telinga tengah, pleura). Menurut Organisasi Kesehatan Dunia (World Health Organization/WHO), ISPA merupakan penyakit saluran pernapasan akut yang disebabkan oleh agen infeksius yang menimbulkan gejala dalam waktu beberapa jam sampai beberapa hari. Menurut Wong (2011) dalam Novikasari (2021), Penyakit ISPA dapat ditularkan melalui air ludah, bersin, udara pernapasan yang mengandung kuman yang terhirup oleh orang sehat kesaluran pernapasannya. Infeksi saluran pernapasan bagian atas terutama yang disebabkan oleh virus, sering terjadi pada semua golongan umur, tetapi ISPA yang berlanjut menjadi Pneumonia sering terjadi pada anak kecil terutama apabila terdapat gizi kurang dan dikombinasi dengan keadaan lingkungan yang tidak hygiene (Wahyudi, dkk. 2021).

ISPA adalah penyebab utama morbiditas dan mortalitas penyakit menular di dunia. Hampir empat juta orang meninggal akibat ISPA setiap tahunnya Selain itu, ISPA merupakan penyebab utama konsultasi atau rawat inap di fasilitas pelayanan kesehatan terutama pada bagian perawatan anak. Hal yang serupa juga terjadi di Indonesia (Maharani, 2017). World Health Organization(WHO) menyebutkan insiden infeksi saluran pernapasan akut (ISPA) dengan angka kematian balita diatas 40 per 1000 kelahiran hidup atau 15\% - $20 \%$ pertahun pada balita. Di Indonesia kasus ISPA masih menempati urutan pertama penyebab kematian pada kelompok bayi dan balita dengan prevalensi $25 \%$ dengan morbiditas gizi kurang $14,9 \%$. Status gizi merupakan faktor resiko penting terjadinya ISPA, status gizi buruk akan membuat sistem kekebalan tubuh menurun dan meningkatkan resiko terjadinya penyakit infeksi (Sulastini, 2018).

Berdasarkan data Kementrian Kesehatan Republik Indonesia (Kemenkes RI) tahun 2019, angka kejadian pneumonia pada balita usia $<1$ tahun sebanyak 158.970 orang dengan angka kematian sebanyak 201 orang. Sedangkan angka kejadian pneumonia pada balita usia 1-4 tahun sebanyak 319.108 orang dengan angka kematian sebanyak 142 orang. Sedangkan kejadian pneumonia di Provinsi Sumatera Selatan berdasarkan data Kemenkes RI tahun 2019, kejadian pneumonia pada balita usia $<1$ tahun sebanyak 4.487 orang dengan angka kematian sebanyak 0 orang. Sedangkan angka kejadian pneumonia pada balita usia 1-4 tahun sebanyak 7.610 orang dengan angka kematian sebanyak 0 orang (Kemenkes, 2018). Berdasarkan data Dinas Kesehatan Kota Palembang, jumlah kasus ISPA pada balita tahun 2015 sebanyak 5.724 kasus, mengalami penurunan pada tahun 2016 sebanyak 5.198 kasus dan tahun 2017 mengalami kenaikan kembali sebanyak 5.783 kasus dari 160.211 balita. Kasus terbanyak terdapat pada kecamatan Sukarami sebanyak 560 kasus dan kasus ISPA terendah terdapat pada 
Kecamatan Sematang Borang sebanyak 140 kasus (Dinkes Kota Palembang, 2018).

Keluarga merupakan bagian dari tim pengobatan dan perawatan. Karena keluarga merupakan unit paling dekat dengan pasien, dan merupakan perawat utama bagi pasien. Keluarga memiliki peran dalam menentukan bagaimana perawatan yang diperlukan pasien saat berada di rumah. Walaupun peawatan di rumah sakit berhasil, tapi jika perawatan di rumah tidak diteruskan maka keberhasilan perawat di rumah sakit akan sia-sia sehingga akan mengakibatkan pasien akan mengalami kekambuhan. Peran serta keluarga mulai dari awal perawatan akan meningkatkan kemampuan keluarga merawat pasien sehingga memungkinkan pasien tidak kambuh atau dapat dicegah (Padila, 2019; Isnaniny. et al, 2020)

Penanganan yang dilakukan masing-masing orang tua berbeda. Menurut penelitian yang dilakukan Florentina (2013) dalam Dary (2018), keterlambatan pencarian layanan kesehatan merupakan salah satu penyebab tingginya kematian akibat ISPA. Faktor-faktor yang dapat memengaruhi perilaku pencarian pelayanan kesehatan antara lain status sosial ekonomi, usia ibu, pendidikan ibu, persepsi orang tua, usia anak, jenis kelamin anak, jumlah balita dalam keluarga

Menurut Padila, (2019) dalam Widianti (2020), Beberapa peranan ibu dalam melakukan upaya perawatan ISPA pada anaknya yaitu ibu harus mengetahui tentang ISPA mulai dari pengertian, penyebab, tanda dan gejala, proses perjalanan penyakit, komplikasi dan cara mengobati dan merawat anak semasa sakitnya tersebut agar bisa melakukan perawatan sedini mungkin dan sudah tahu bagaimana cara pencegahan ISPA tersebut

Dalam penelitian Dary (2018) menjelaskan bahwa Pengobatan tradisional merupakan pengobatan yang pertama kali dilakukan partisipan bila ada balitanya yang tiba-tiba sakit, dengan cara menggosokan minyak kayu putih ataupun dibawa ke tukang urut. Jika pengobatan tradisional tidak membuahkan hasil barulah keluarga membawa balita berobat ke RS untuk mendapatkan obat dari tenaga kesehatan. Selain itu, saat di rumah keluarga memberikan beberapa perlakuan khusus kepada anak dengan penyakit ISPA yaitu menggosokan minyak kayu putih, menjaga kebersihan diri anak, dan lingkungan sekitar tempat tinggal, dengan harapan agar anak cepat sembuh dan dapat beraktifitas seperti anak-anak yang lain.

Peran aktif orang tua dalam menangani ISPA sangat penting.Orang tua seringkali menganggap batuk pilek adalah penyakit yang tidak berbahaya, akan tetapi penyakit ini bisa menjadi berat bila daya tahan tubuh menurundan tidak diobati (Ngastiyah, 2012). Jika anak yang terkena SPA dibiarkan tidak diobati dapat mengakibatkan penyebaran infeksi yang lebih luas sehingga infeksi menyerang saluran nafas bagian bawah dan menyebabkan radang paru atau pneumonia (Ambarsari, 2014)

Yang dapat dilakukan ibu di rumah yaitu mengatasi panas (demam) dengan memberikan obat tablet paracetamol atau mengompres anak dengan menggunakan kain bersih, celupkan pada air tiga kali sehari. Mengatasi batuk dengan obat yang aman yaitu ramuan tradisional terbuat dari jeruk nipis $1 / 2$ sendok teh dicampur dengan kecap atau madu $1 / 2$ sendok teh diberikan tiga kali sehari. Pemberian makanan yang cukup gizi, sedikit-sedikit tetapi berulangulang yaitu lebih sering dari biasanya, lebih-lebih jika muntah dan pemberian cairan dengan mengusahakan pemberian cairan (air putih, air buah, dsb) lebih banyak dari biasanya akan membantu mengencerkan dahak, kekurangan cairan menambah parah sakit yang diderita anak. (Suryanti, 
2016). Susanto (2017) menjelaskan penanganan optimal bagi penderita memerlukan peranan ibu sebagai mekanisme untuk menurunkan dampak masalah kesehatan pada anak dan keluarganya. Pengetahuan ibu yang benar tentang ISPA dapat membantu mendeteksi dan mencegah penyakit ISPA lebih awal. Perawatan ISPA meliputi mengatasi panas (demam), pemberian makanan yang cukup gizi, pemberian cairan, memberikan kenyamanan, dan memperhatikan tanda-tanda bahaya ISPA ringan atau berat yang memerlukan bantuan khusus petugas kesehatan.

Berdasarkan uraian di atas, maka penulis tertarik melakukan pengabdian masyarakat dengan judul penanganan ISPA selama di Rumah pada Anak di RT 13 Keluarahan Pulokerto Kecamatan Gandus Palembang.

\section{MASALAH}

Alasan memilih tempat kegiatan pengabdian kepada masyarakat di RT 13 Kelurahan Pulokerto Kecamatan Gandus adalah Berdasarkan studi pendahuluan di lingkungan RT 13 Kelurahan Pulokerto Kecamatan Gandus didapatkan bahwa sumber air masih menggunakan air sungai, perilaku hidup bersih dan sehat yang masih kurang, rumah penduduk yang padat, lingkungan di sekitar kotor dikarenakan di lingkungan tersebut terdapat pasar. Selain itu pengetahuan masyarakat masih kurang. Dan tujuan dari pengabdian kepada masyarakat ini, peserta mengerti dan memahami bagaimana penanganan ISPA pada anak.

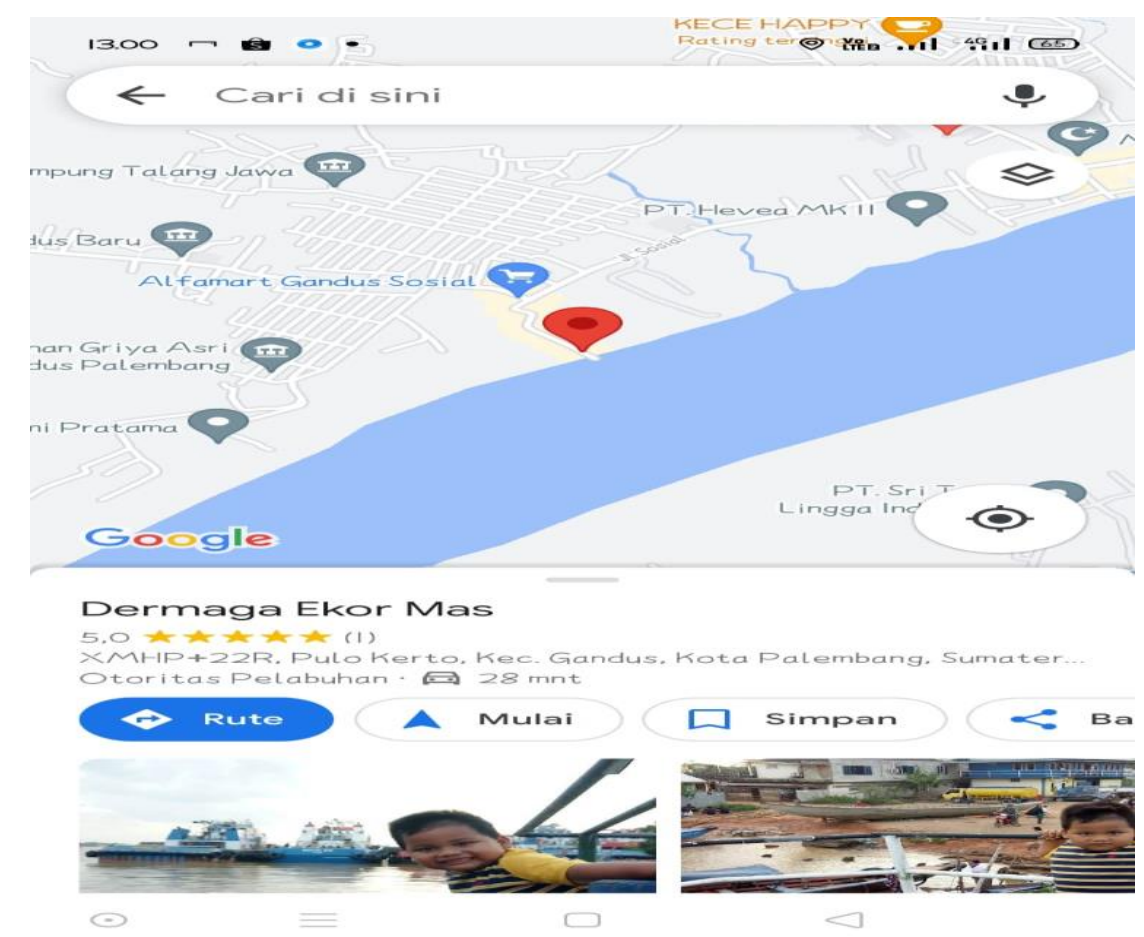

Gambar 2.1 Peta Lokasi Kegiatan Pengabdian Kepada Masyarakat 


\section{METODE}

\section{a. Tujuan Persiapan}

Tahap persiapan dari kegiatan pengabdian masyarakat ini adalah dimulai dengan survey lapangan ke lokasi, kemudian mempersiapkan administrasi perizinan ke ketua RT. Setelah mendapat izin dari RT, kemudian menyiapkan bahan untuk penyuluhan seperti leaflet. Kemudian di tanggal 23 Juli 2021 dilakukan penegcekan tempat penyuluhan yaitu dilakukan di mushola.

\section{b. Tahap Pelaksanaan}

Kegiatan ini dengan pemberitahuan dari Ketua RT 13 untuk mengarahkan masyarakat untuk berkumpul di Musholla. Dan dilanjutkan dengan penyuluhan tentang Penatalaksanaan ISPA pada Anak. Metode kegiatan ini berbentuk penyuluhan kesehatan dengan metode ceramah tentang ISPA dan cara penangangan ISPA pada anak.

c. Evaluasi

i. Struktur

Peserta hadir sebanyak 20 orang masyarakat ketua RT 13. Setting tempat sudah sesuai dengan rencana yang dibuat dan perlengkapan yang dilakukan untuk penyuluhan sudah tersedia. Pada saat materi berakhir di berikan evaluasi ke masyarakat yang mengikuti penyuluhan dengan mudah mereka bisa menjawab pertanyaanpertanyaan yang di berikan serta ada beberapa masyarakat memberikan pertanyaan terkait hal yang belum mereka pahami

ii. Proses

Pelaksanaan kegiatan penyuluhan pukul 10.00 s.d 11.00 .

\section{HASIL DAN PEMBAHASAN}

Proses pelaksanaan dalam kegiatan Penyuluhan dengan tema penanganan ISPA pada anak Di Rt 13 Kelurahan Pulokerto Kecamatan Gandus Palembang Tahun 2021 telah dilaksanakan pada tanggal 24 Juli 2021. Kegiatan berlangsung dari pukul 10.00- 11.00 wib. Pelaksanaan penyuluhan ditujukan pada masyarakat setempat dengan media dan alat yang digunakan yaitu leaflet. Penyampaian materi dengan metode ceramah dan diskusi mengenai penanganan ISPA pada anak.

Pada saat materi berakhir di berikan evaluasi ke masyarakat yang mengikuti penyuluhan dengan mudah mereka bisa menjawab pertanyaanpertanyaan yang di berikan serta ada beberapa masyarakat memberikan pertanyaan terkait hal yang belum mereka pahami, kegiatan ini harapannya ke depan bisa dilaksanakan secara berkesinambungan karena memang lokasi kegiatan penyuluhan ini merupakan lokasi desa binaan prodi DIII keperawatan. Berikut gambar pelaksanaan penyuluhan yang telah di lakukan: 


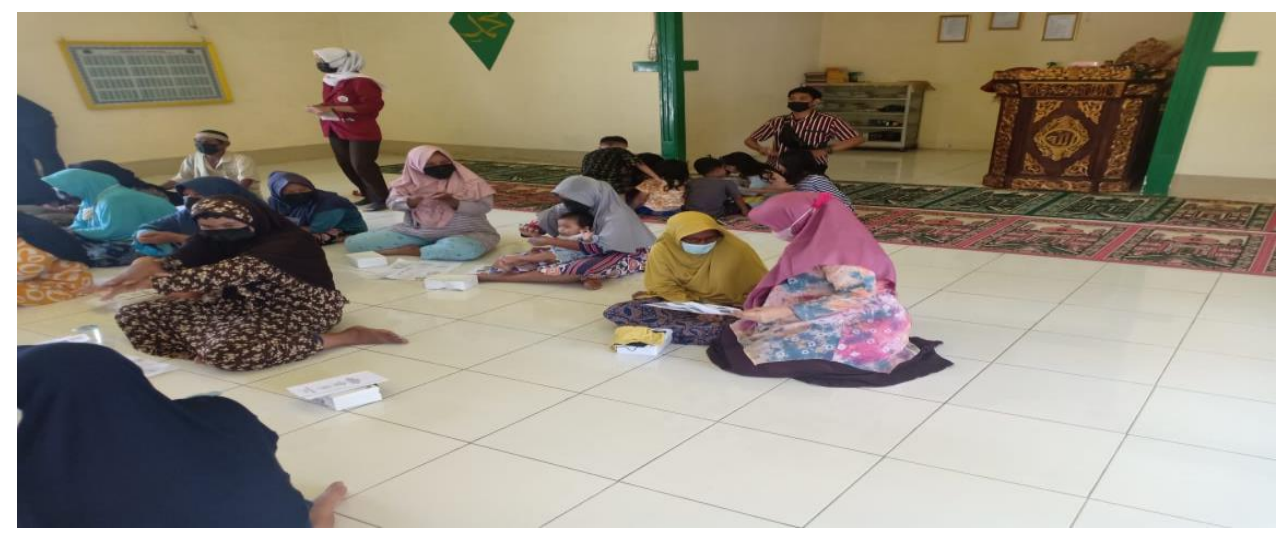

Gambar 5.1 Foto Kegiatan PkM

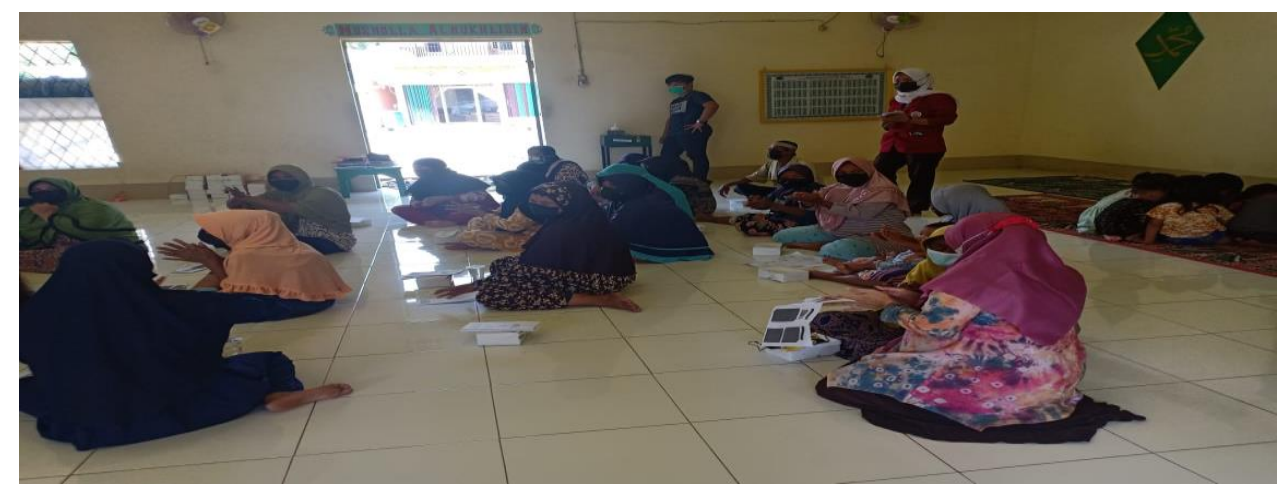

Gambar 5.2 Foto Kegiatan PkM

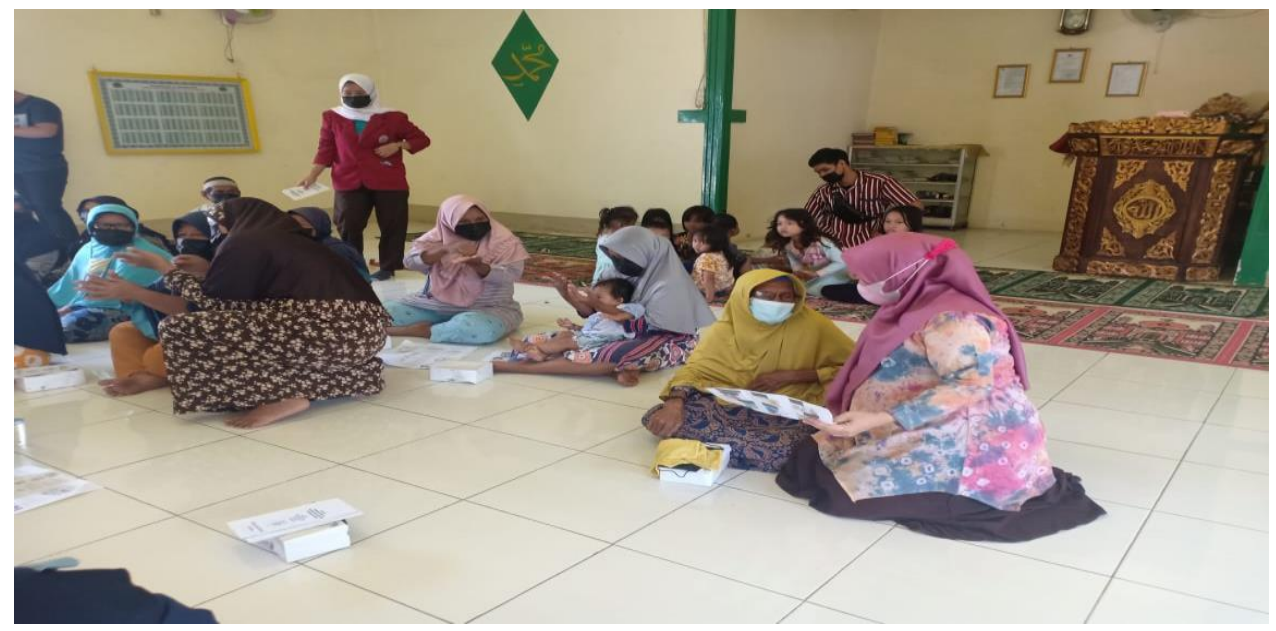

Gambar 5.3 Foto Kegiatan PkM

\section{KESIMPULAN}

Pengabdian masyarakat dengan topik "Penanganan ISPA pada Anak khususnya di RT 13 Kelurahan Pulokerto Kecamatan Gandus Palembang Tahun 2021" telah terlaksana dengan baik. Masyarakat setempat telah mendapatkan penyuluhan dan penjelasan yang jelas dan mudah dipahami mengenai penanganan ISPA pada anak. 


\section{DAFTAR PUSTAKA}

Alfian, R., Susanto, Y., \& Khadizah, S. (2017). Kualitas Hidup Pasien Hipertensi Dengan Penyakit Penyerta Di Poli Jantung RSUD Ratu Zalecha Martapura. Jurnal Pharmascience, (4): 39-47.

Dary. (2018). Peran Keluarga Dalam Penanganan Anak dengan Penyakit ISPA Di RSUD Piru. Jurnal Keperawatan Muhammadiyah 3 (1) 2018

Maharani D, Yani FF. Artikel Penelitian Profil Balita Pasienlnfeksi Saluran Nafas Akut Atas di RSUP dr. M. Djamil Padang. 2013;6(1):152-7.

Ngastiyah. (2012). Perawatan anak sakit.Edisi II.Jakarta: EGC

Novikasari, dkk. (2021). Pengabdian Terhadap Masyarakat Pada Balita Menderita Ispa Menggunakan Terapi Komplementer Fisiotrapi Dada. Jurnal Kreativitas Pengabdian Kepada Masyarakat (Pkm), P-Issn: 2615-0921 E-Issn: 2622-6030 Volume 4 Nomor 2 Tahun 2021] Hal 464-469.

Padila. (2019). Buku Ajar: Keperawatan Medikal Bedah. Edisi 3. Yogjakarta: Nuha Medika.

Dinas Kesehatan Kota Palembang. (2018). Profil Dinas Kesehatan Kota Palembang.

Kementerian Kesehatan RI. (2018). Profil Kementerian Kesehatan Republik Indonesia.

Kementerian Kesehatan RI. (2019). Profil Kementerian Kesehatan Republik Indonesia.

Isnainy, U. C. A. S., Zainaro, M. A., Novikasari, L., Ariyanti, L., \& Furqoni, P. D. (2020). Pendidikan Kesehatan Tentang Perilaku Hidup Bersih Dan Sehat (PHBS) di SMA Negeri 13 Bandar Lampung. Jurnal Kreativitas Pengabdian Kepada Masyarakat (PKM), 3(1), 27-33.

Wahyudi, W. T., Zainaro, M. A., \& Kurniawan, M. (2021). Hubungan Paparan Asap Rokok Dengan Kejadian Ispa Pada Balita Di Wilayah Kerja Puskesmas Bandar Agung Kecamatan Terusan Nunyai Kabupaten Lampung Tengah. Malahayati Nursing Journal, 3(1), 82-91.

Widianti, S. (2020). Penanganan ISPA pada Anak Balita. Jurnal Kesehatan dan Pembangunan, Vol.10, No.20, Juli 2020.

Wong, D, dkk. (2009). Buku Ajar Keperawatan Pediatrik. Volume 1. Penerbit. Buku Kedokteran EGC : Jakarta 